\title{
ISOLATION AND CHARACTERIZATION OF CAULOBACTER MUTANTS IMPAIRED IN ADAPTATION TO STATIONARY PHASE
}

\author{
Valéria C. S. Italiani; Marilis V. Marques* \\ Departamento de Microbiologia, Instituto de Ciências Biomédicas, Universidade de São Paulo, São Paulo, SP, Brasil.
}

Submitted: October 02, 2002; Approved: February 12, 2002

\begin{abstract}
The entry into stationary phase causes a change in the pattern of gene expression of bacteria, when the cells must express a whole set of genes involved mainly with resistance to starvation and to environmental stresses. As an attempt to identify genes important for the survival of Caulobacter crescentus in stationary phase, we have screened a library of 5,000 clones generated by random transposon mutagenesis for mutants that showed reduced viability after prolonged growth. Four clones were selected, which displayed either lower viability or a longer time of recovery from stationary phase. The genes disrupted were identified, and the gene products were found to be mainly involved with amino acid metabolism (glutamate $\mathrm{N}$-acetyltransferase, 4-hydroxyphenylpyruvate dioxygenase and L-aspartate oxidase) or with recombination (exonuclease RecJ). Each mutant was tested for resistance to stresses, such as oxidative, saline, acidic, heat and UV exposure, showing different responses. Although the mutations obtained were not in genes involved specifically in stationary phase, our results suggest that amino acids metabolism may play an important role in keeping viability during this growth phase.
\end{abstract}

Key words: Stationary phase, stress, transposon, bacteria

\section{INTRODUCTION}

The onset of stationary phase in bacteria is one of the best examples of global gene regulation, when several key regulatory factors act coordinately to stablish a new pattern of gene expression. The proteins synthesized by the cell during the entry into stationary phase are involved in keeping viability throughout long periods of starvation. The total protein synthesis is reduced to about $20 \%$ of that found in exponentially growing cells in minimal medium (1), and this drops to $0.5 \%$ after 11 days in stationary phase (reviewed in 13).

In non-sporulating Gram negative bacteria, nutritional deprivation leads the cells to be more resistant to cold shock, oxidative stress and osmotic variations (13). Several proteins induced upon stationary phase are also induced by specific stresses, like high osmolarity, high temperature or acidic $\mathrm{pH}$ $(9,10,15,18)$. E. coli cells submitted to these stresses show phenotypes typical of stationary phase cells, like smaller cells and multiple stress resistance $(10,22)$.

In $E$. coli and other bacteria the main regulator of this phase is a sigma factor $\left(\sigma^{\mathrm{S}}\right.$ in E. coli, $\sigma^{\mathrm{H}}$ in Bacillus $)$, which is responsible for the induction of several genes required at this stage $(2,10)$. The $\sigma^{\mathrm{S}}$ factor in Pseudomonas, $\sigma^{\mathrm{B}}$ in Bacillus and other transcription factors of stationary phase from Rhizobium and Vibrio are also regulated by quorum sensing, indicating an interconnection between quorum sensing and starvationsensing pathways (14).

C. crescentus is an aquatic bacterium belonging to the alpha subfamily of the proteobacteria, and no homolog of $\sigma^{S}$ was identified in the genome sequence (19), suggesting that the regulation of stationary phase genes could be carried out by a different system. A previous work showed that when in late stationary phase Caulobacter undergoes a morphological change and display increased resistance to stress (29). Very few

\footnotetext{
* Corresponding author. Mailing Address: Departamento de Microbiologia, Instituto de Ciências Biomédicas II, Universidade de São Paulo. Av. Prof. Lineu Prestes, 1374, Cidade Universitária. 05508-900, São Paulo, SP, Brasil
} 
proteins induced in this phase have been identified in Caulobacter, such as the FstH (7), and the ClpXP proteases (20), and some that are involved in stress response, as a catalase/ peroxidase and a superoxide dismutase (23).

This work aims to identify genes from Caulobacter that are important for survival to stationary phase through transposon mutagenesis and isolation of mutants, and to characterize the stress resistance phenotype of the mutants isolated.

\section{MATERIALS AND METHODS}

\section{Bacterial strains and media}

C. crescentus NA1000 strain (6) was used as wild type for all experiments. Cells were grown at $30^{\circ} \mathrm{C}$ in peptone yeast extract (PYE) or M2 minimal medium (5), supplemented with kanamycin $(5 \mu \mathrm{g} / \mathrm{ml})$ as necessary.

\section{Isolation of stationary phase deficient mutants from a $C$.} crescentus transposition library

Tn5 (Kan) transposon was inserted into C. crescentus strain NA1000 by conjugation with an $E$. coli S17-1 carrying plasmid pSUP2021 (25) as described (12). Screeening was performed as described previously (28), with the following modifications: the cells were grown in 96-well plates containing $0.3 \mathrm{ml}$ of PYE/Kan medium at $30^{\circ} \mathrm{C}$ for 14 days with agitation, followed by plating in PYE/Kan. Strains that showed reduced or no colonies in the plates were selected for further confirmation, now repeating the long term growth in larger culture volumes.

\section{Identification of the Tn5 insertion sites}

The determination of the Tn5 insertion sites was performed by reverse PCR as described (12). The PCR conditions were: 5 minutes $95^{\circ} \mathrm{C}, 30$ cycles of 1 minute $95^{\circ} \mathrm{C}, 1$ minute $42^{\circ} \mathrm{C}$ or $52^{\circ} \mathrm{C}$ and 1 minute $72^{\circ} \mathrm{C}$, and a final cycle of 7 minutes at $72^{\circ} \mathrm{C}$. The bands obtained were gel purified and cloned into the TOPO vector (Invitrogen). The recombinant plasmids were used for automatic DNA sequencing with BigDye terminators on a ABI Prism 377 sequencer (AP Biosystems). The insertion site was determined by comparison to the complete $C$. crescentus genome sequence (19).

\section{Stress viability tests}

Cell survival was measured by counting the C.F.U./ml after colonies were grown, using the $C$. crescentus NA1000 strain as a control to all experiments. Midlog phase cultures of each mutant were incubated under several stress conditions, aliquots were taken during several times after addition of the stress agent and then serial dilutions of the culture were plated in PYE/Kan. All the experiments were repeated at least three times.

To determine viability under oxidative stress, $\mathrm{H}_{2} \mathrm{O}_{2}$ was added to the culture at a final concentration of $10 \mathrm{mM}$. The tests for survival under acid ( $\mathrm{pH} 4.0)$ conditions were as follows: $2 \mathrm{ml}$ of each culture was centrifuged and the cells were ressuspended in the same volume of PYE medium adjusted to $\mathrm{pH} 4.0$ with $\mathrm{HCl}$, as described by Wortinger et al. (29). In the heat stress survival test, a midlog culture was transferred to $45^{\circ} \mathrm{C}$ and samples were taken at several time points for plating. UV survival was determined by plating the same number of exponential growing cells of each strain in PYE medium, and exposing the plates in the dark to a UV lamp (220-300 nm, $2 \mathrm{~J} / \mathrm{m}^{2}$.s) for different times. Plates were incubated at $30^{\circ} \mathrm{C}$ protected from light and the number of colonies formed after 5 days was counted. To test the response to high salt concentration, $\mathrm{NaCl}$ was added to the exponential phase cultures to a final concentration of $85 \mathrm{mM}$.

\section{RESULTS AND DISCUSSION}

Caulobacter undergoes a unique developmental program where two dissimilar daughter cells are generated at each cell division, which indicates that its adaptation to stationary phase must probably be a complex event. As an attempt to identify genes that are important to the survival of $C$. crescentus at stationary phase, we have screened a transposon library of 5,000 clones in search for mutants that showed a defective growth phenotype after prolonged time of incubation. The cultures were incubated for 14 days, when cells show the elongated morphology characteristic of late stationary phase (29), and then plated in rich medium. Four mutant strains were selected which showed either lower cell viability or a delay in the appearing of colonies, what could suggest a defect in recovery from stationary phase (Table 1).

In order to identify the genes that were disrupted by the transposon in each strain, the Tn5 insertion site was determined by DNA sequencing. The disrupted genes encode enzymes that are related mostly to metabolic functions (Table 1). In mutant $16-3 \mathrm{~A}$, the disrupted gene $(\arg J)$ encodes the glutamate $\mathrm{N}-$ acetyltransferase, which is required for the biosynthesis of arginine. This mutant is unable to grow in minimal medium, confirming that it is deficient in a biosynthetic pathway (not shown). In mutant 25-3C, the Tn5 integrated into the gene encoding the 4-hydroxyphenylpyruvate dioxygenase (HPPD), which is involved in the degradation of phenylalanine and tyrosine (17). In both cases, the integration of the Tn5 most likely did not afect the expression of other genes downstream, since one is in the opposite direction (16-3A) and the other is separated by 180 bp (25-3C) (Fig. 1).

In mutant 9-12D, the transposon inserted into the $\operatorname{nadB}$ gene, which encodes the enzyme L-aspartate oxidase. This gene is the first one in a probable operon (Fig. 1) in a gene locus for NAD biosynthesis, consisting of genes $\operatorname{nadA}$, $\operatorname{nadB}$ and $n a d C$, and the integration of the Tn5 likely has also an effect in the expression of the genes downstream of $n a d B$. 
Table 1. Identification and phenotype of the stationary phase mutants isolated.

\begin{tabular}{cccc}
\hline Mutant & Disrupted ORF ID $^{\text {a }}$ & Putative product function & Stationary phase phenotype $^{\mathrm{b}}$ \\
\hline 9-12D & AAK24875 (CC2913) & L-aspartate oxidase & longer recovery \\
16-3A & AAK25028 (CC3066) & glutamate N-acetyltransferase & longer recovery \\
25-3C & AAK24504 (CC2533) & 4-hydroxyphenylpyruvate dioxygenase & lower viability \\
49-1C & AAK23367 (CC1386) & single-stranded-DNA-specific exonuclease RecJ & lower viability \\
\hline
\end{tabular}

${ }^{\mathrm{a}}$ Numbers in parenthesis indicate the gene ID; ${ }^{\mathrm{b}}$ Viability was determined by counting the C.F.U. of each strain after incubation for 14 days in PYE medium. Time of recovery was determined as the amount of time required for colonies to reach a visible size, compared to the average time of the NA1000 strain, of serial dilutions plated after a 14 day incubation in PYE medium.

Mutations in the nadB gene from E. coli, S. typhimurium and B. subtilis turn them auxotrophic for nicotinic acid, therefore the $\operatorname{nadB}$ gene is essential for NAD biosynthesis in these bacteria $(3,8,27)$. However, the $n a d B$ gene in Caulobacter is not essential, since mutant 9-12D does not need nicotinic acid for growth (not shown), indicating there must be an alternative biosynthetic route, as suggested for Pseudomonas (4).

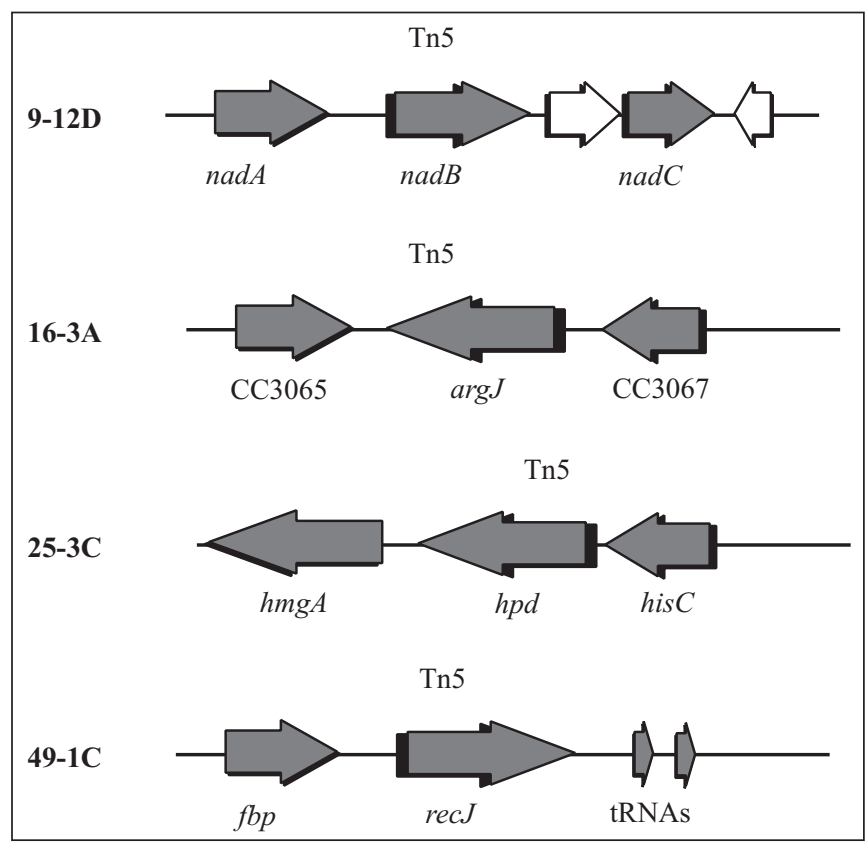

Figure 1. Schematic representation of the genomic regions containing the disrupted genes in each mutant strain. The gray arrows indicate open reading frames of proteins with known functions, and white arrows indicate open reading frames of hypothetical proteins. The directions of the arrows represent the direction of transcription. The Tn5 insertion site is indicated by the triangle. Gene nomenclature follows the annotated C. crescentus genome at the TIGR site (http:// www.tigr.org).
In mutant $49-1 \mathrm{C}$, the disrupted gene encodes the singlestranded-DNA-specific exonuclease RecJ, which is involved both in homologous and illegitimate recombination (24). recJ mutants show decreased DNA repair ability, and are therefore highly sensitive to low levels of UV irradiation and to exposure to DNA-alkylating agents $(11,26)$. This gene is not transcribed with any other gene downstream (Fig. 1).

The mutant strains were then tested for their ability to withstand several environmental stresses, to determine whether their poor performance in stationary phase could be an effect of a more general stress-sensitive phenotype. The cells were tested for oxidative, saline, acidic, heat and UV exposure (Fig. 2), at conditions in which the wild type cells were not affected (12). As a second control, a mutant strain with the Tn5 inserted into the $r s a F$ gene that encodes an outer membrane protein (OMP58) was tested for all stresses and responded like the wild type, indicating that the sensitivity to stress is not due to the presence of the Tn5 (not shown).

As it can be observed in Fig. 2, each strain showed a different pattern of response to individual stresses, but some general patterns can be pointed out. Mutant 16-3A did not show a particularly sensitive phenotype in any of the conditions. The deficiency in amino acid biosynthesis in 16$3 \mathrm{~A}$ probably is responsible for a slow recovery from the nutrient starvation, causing the delay in colony formation observed in the screening proccess. Mutant 9-12D displayed decreased viability in acidic $\mathrm{pH}$ and $\mathrm{UV}$ light at longer time points, suggesting that despite the fact that the $\operatorname{nadB}$ gene is not essential for Caulobacter, its loss causes it to be more sensitive to some stresses.

Mutant 25-3C showed lower viability under oxidative stress, heat shock and UV at the 30 min time point, indicating that HPPD is important for the cell under stress conditions. In Sinorhizobium meliloti, a mutant disrupted in the hmgA gene, which encodes for another enzyme of the degradative pathway of tyrosine and phenylalanine, was described as showing deficiency in stationary phase survival (17).

Mutant 49-1C showed the most sensitive phenotype, with reduced viability under all the conditions tested. Oxidative stress generated by $\mathrm{H}_{2} \mathrm{O}_{2}$ can enhance DNA lesions, and it has been 

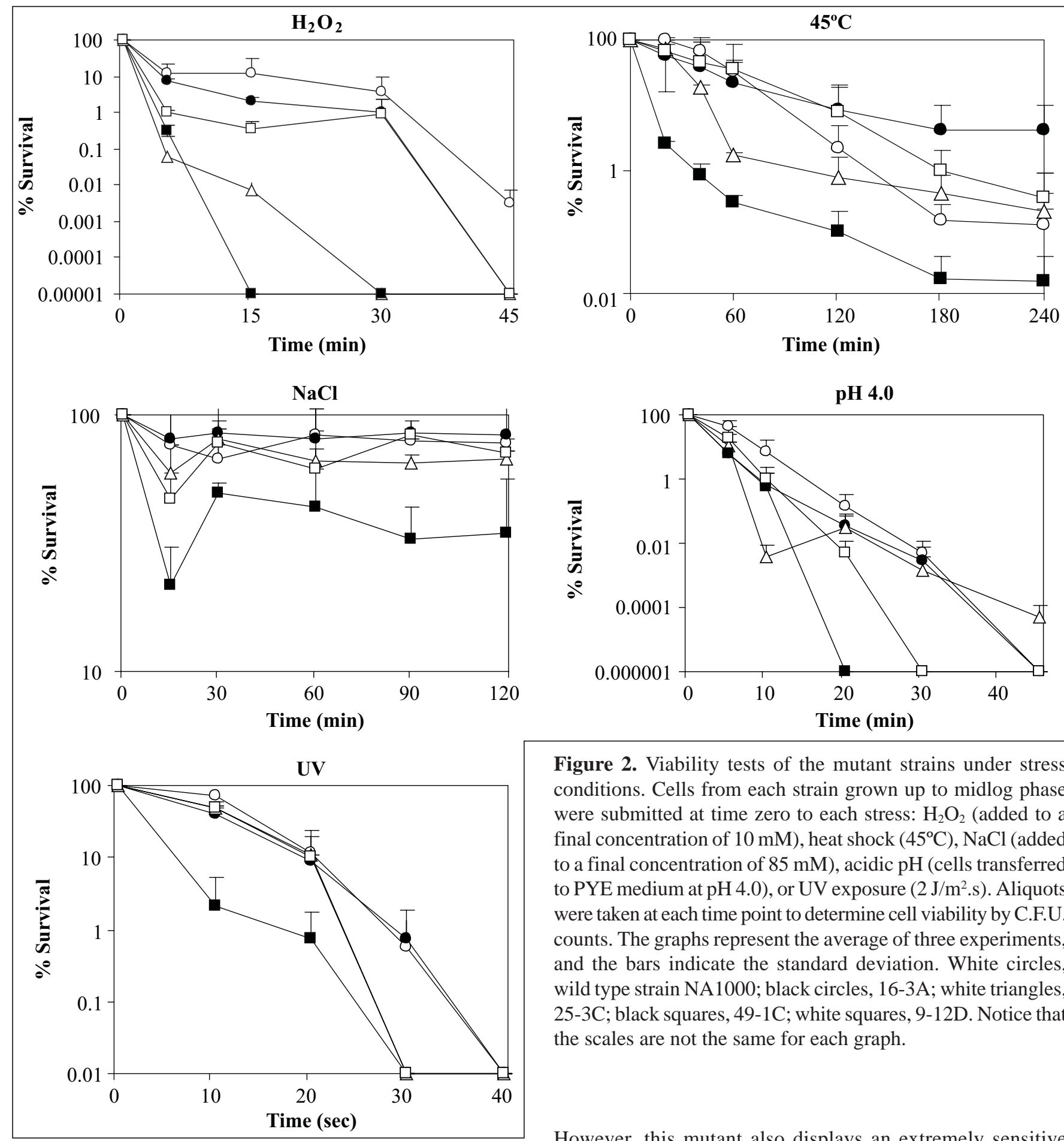

Figure 2. Viability tests of the mutant strains under stress conditions. Cells from each strain grown up to midlog phase were submitted at time zero to each stress: $\mathrm{H}_{2} \mathrm{O}_{2}$ (added to a final concentration of $10 \mathrm{mM}$ ), heat shock $\left(45^{\circ} \mathrm{C}\right), \mathrm{NaCl}$ (added to a final concentration of $85 \mathrm{mM}$ ), acidic $\mathrm{pH}$ (cells transferred to PYE medium at $\mathrm{pH} 4.0)$, or $\mathrm{UV}$ exposure $\left(2 \mathrm{~J} / \mathrm{m}^{2} . \mathrm{s}\right)$. Aliquots were taken at each time point to determine cell viability by C.F.U. counts. The graphs represent the average of three experiments, and the bars indicate the standard deviation. White circles, wild type strain NA1000; black circles, 16-3A; white triangles, 25-3C; black squares, 49-1C; white squares, 9-12D. Notice that the scales are not the same for each graph.

However, this mutant also displays an extremely sensitive phenotype under heat shock, and an intermediate survival rate in saline and acidic stress, indicating that a mutation in recJ has probably a pleiotropic effect.

In $E$. coli, it is well stablished that there is intense protein RecA in Xanthomonas campestris (21). Therefore, a lower viability under $\mathrm{UV}$ irradiation and in the presence of $\mathrm{H}_{2} \mathrm{O}_{2}$ was expected, since the recJ gene is required for DNA repair. degradation to recycle amino acids during stationary phase (16). Our results suggest that amino acids metabolism may play 
an important role in keeping viability during this phase. This hypothesis was also discussed in a work in S. meliloti, where a mutant deficient in degradation of leucine, valine and isoleucine had also a stationary phase phenotype (28). More recently, it was shown that three mutations in the $r p o S$ gene from $E$. coli cause a growth advantage in stationary phase, and enhance amino acid catabolism (30). In this work the mutations selected were not in genes involved specifically in stationary phase, which indicates that the viability in this phase is dependent on many interdependent pathways, and probably no single mutation could have a phenotype. Another possibility is that disruption of such genes could be lethal for the cell, and therefore mutants could not be isolated.

\section{ACKNOWLEDGEMENTS}

This work was supported by Fundação de Amparo à Pesquisa do Estado de São Paulo (FAPESP). During the course of this work, V.C.S.I. was supported by fellowship from FAPESP.

\section{RESUMO}

\section{Isolamento e caracterização de mutantes de Caulobacter deficientes na adaptação à fase estacionária}

A entrada em fase estacionária causa uma mudança no padrão de expressão gênica de bactérias, quando as células devem expressar um novo conjunto de genes envolvidos principalmente com resistência à carência alimentar e a estresses ambientais. Em uma tentativa de identificar genes importantes para a sobrevivência de Caulobacter crescentus em fase estacionária, nós varremos uma biblioteca de 5.000 clones gerados por transposição aleatória em busca de mutantes que mostrassem viabilidade reduzida após crescimento prolongado. Quatro clones foram selecionados, que mostraram menor viabilidade ou um maior tempo de recuperação da fase estacionária. Os genes interrompidos foram identificados, e os produtos gênicos mostraram-se estar envolvidos principalmente com o metabolismo de aminoácidos (glutamato $\mathrm{N}$ acetiltransferase, 4-hidroxifenilpiruvato dioxigenase e Laspartato oxidase) ou com recombinação (exonuclease RecJ). Cada mutante foi testado para resistência a estresses, como oxidativo, salino, ácido, calor e exposição à luz UV, mostrando respostas diferentes. Embora as mutações obtidas não tenham sido em genes envolvidos especificamente com fase estacionária, nossos resultados sugerem que o metabolismo de aminoácidos tem papel importante na manutenção da viabilidade durante esta fase do crescimento.

Palavras-chave: fase estacionária, estresse, transposon, bactéria.

\section{REFERENCES}

1. Albertson, N.H.; Nystrom, T.; Kjelleberg, S. Macromolecular synthesis during recovery of the marine Vibrio sp. S14 from starvation. J. Gen. Microbiol., 136: 2201-07, 1990.

2. Britton, R.A.; Eichenberger, P.; Gonzalez-Pastor, J.E.; Fawcett, P.; Monson, R.; Losick, R.; Grossman, A.D. Genome-wide analysis of the stationary-phase sigma factor (sigma-H) regulon of Bacillus subtilis. J. Bacteriol., 184: 4881-90, 2002.

3. Cookson, B.T.; Oliveira, B.M.; Roth, J.R. Genetic characterization and regulation of the $n a d B$ locus of Salmonella typhimurium. J. Bacteriol., 169: 4285-93, 1987.

4. DeVries, C.A.; Hassett, D.J.; Flynn, J.L.; Ohman, D.E. Genetic linkage in Pseudomonas aeruginosa of altT and nadB: mutation in $n a d B$ does not affect NAD biosynthesis or alginate production. Gene, 156: 63-7, 1995.

5. Ely, B. Genetics of Caulobacter crescentus. Methods. Enzymol., 204: 372-84, 1991

6. Evinger, M.; Agabian, N. Envelope-associated nucleoid from Caulobacter crescentus stalked and swarmer cells. J. Bacteriol., 132: 294-301, 1977.

7. Fischer, B.; Rummel, G.; Aldridge, P.; Jenal, U. The FtsH protease is involved in development, stress response and heat shock control in Caulobacter crescentus. Mol. Microbiol., 44: 461-78, 2002.

8. Foster, J.W.; Moat, A.G. Nicotinamide adenine dinucleotide biosynthesis and pyridine nucleotide cycle metabolism in microbial systems. Microbiol. Rev., 44: 83-105, 1980.

9. Hengge-Aronis, R. Back to log phase: $\sigma^{\varsigma}$ as a global regulator in the osmotic control of gene expression in Escherichia coli. Mol. Microbiol., 21: 887-93, 1996.

10. Hengge-Aronis, R. Survival of hunger and stress: the role of rpoS in early stationary phase gene regulation in Escherichia coli. Cell, 72: 165-68, 1993.

11. Hill, S.A. Neisseria gonorrhoeae recJ mutants show defects in recombinational repair of alkylated bases and UV-induced pyrimidine dimers. Mol. Gen. Genet., 264: 268-75, 2000.

12. Italiani, V.C.S.; Zuleta, L.F.G.; Marques, M.V. The transcription termination factor Rho is required for oxidative stress survival in Caulobacter crescentus. Mol. Microbiol., 44: 181-194, 2002.

13. Kolter, R.; Siegele, D.A.; Tormo, A. The stationary phase of the bacterial life cycle. Annu. Rev. Microbiol., 47: 855-74, 1993.

14. Lazazzera, B.A. Quorum sensing and starvation: signals for entry into stationary phase. Curr. Opin. Microbiol., 3: 177-182, 2000.

15. Lee, I.S.; Lin, J.; Hall, H.K.; Bearson, B.; Foster, J.W. The stationaryphase sigma factor $\sigma^{s}$ (RpoS) is required for a sustained acid tolerance response in virulent Samonella typhimurium. Mol. Microbiol., 17: 155-67, 1995

16. Matin, A.; Auger, E.A.; Blum, P.H.; Schultz, J.E. Genetic basis of starvation survival in non-differentiating bacteria. Annu. Rev. Microbiol., 43: 293-316, 1989.

17. Milcamps, A. \& Bruijn, F.J. Identification of a novel nutrientdeprivation-induced Sinorhizobium meliloti gene ( $h m g A)$ involved in the degradation of tyrosine. Microbiology, 145: 935-47, 1999.

18. Muffler, A.; Barth, M.; Marschall, C.; Hengge-Aronis, R. Heat shock regulation of $\sigma^{\mathrm{s}}$ turnover: a role for DnaK and relationship between stress responses mediated by $\sigma^{\mathrm{s}}$ and $\sigma^{32}$ in Escherichia coli. $J$. Bacteriol., 179: 445-52, 1997.

19. Nierman, W.C., et al. Complete genome sequence of Caulobacter crescentus. Proc. Natl. Acad. Sci. USA, 98: 4136-41, 2001.

20. Osteras, M.; Jenal, U. Regulatory circuits in Caulobacter. Curr. Opin Microbiol., 3: 171-6, 2000.

21. Rabibhadana, S.; Chamnongpol, S.; Sukchawalit, R.; Ambulos, N.P. Jr; Trempy, J.E.; Mongkolsuk, S. Characterization and expression analysis of a Xanthomonas oryzae pv. oryzae recA. FEMS Microbiol. Lett., 158: 195-200, 1998.

22. Santos, J.M.; Freire, P.; Vicente, M.; Arraino, C.M. The stationaryphase morphogene bolA from Escherichia coli is induced by stress during early stages of growth. Mol. Microbiol., 32: 789-98, 1999. 
23. Schnell, S.; Steinman, H.M. Function and stationary-phase induction of periplasmic copper-zinc superoxide dismutase and catalase/ peroxidase in Caulobacter crescentus. J. Bacteriol., 177: 5924-9, 1995.

24. Shiraishi, K.; Hanada, K.; Iwakura, Y.; Ikeda, H. Roles of RecJ, $\mathrm{RecO}$, and RecR in RecET-mediated illegitimate recombination in Escherichia coli. J. Bacteriol., 184: 4715-21, 2002

25. Simon, R.; Priefer, U.; Puhler, A. A broad host range mobilization system for in vivo genetic engineering: transposon mutagenesis in gram negative bacteria. Biotechnology, 1: 784-90, 1983.

26. Skaar, E.P.; Lazio, M.P.; Seifert, H.S. Roles of the recJ and recN genes in homologous recombination and DNA repair pathways of Neisseria gonorrhoeae. J. Bacteriol., 184: 919-27, 2002.
27. Sun, D.; Setlow, P. Cloning, nucleotide sequence, and regulation of the Bacillus subtilis nadB gene and nifS-like gene, both of which are essencial for NAD biosynthesis. J. Bacteriol., 175: 1423-32, 1993.

28. Uhde, C.; Schmidt, R.; Jording, D.; Selbitschka, W.; Puhler, A. Stationary-phase mutants of Sinorhizobium meliloti are impaired in stationary-phase survival or in recovery to logarithmic growth. $J$. Bacteriol., 179: 6432-40, 1997.

29. Wortinger, M.A.; Quardokus, E.M.; Brun, Y.V. Morphological adaptation and inhibition of cell division during stationary phase in Caulobacter crescentus. Mol. Microbiol., 29: 963-73, 1998.

30. Zinser, E.R.; Kolter, R. Mutations enhancing amino acid catabolism confer a growth advantage in stationary phase. J. Bacteriol., 181: 5800-07, 1999. 